\title{
PENGARUH PENGALAMAN EKONOMI, KONTROL DIRI SERTA PENDAPATAN SISWA TERHADAP PERILAKU EKONOMI SISWA SMA DI KECAMATAN PASIR BELENGKONG KABUPATEN PASER
}

\author{
Ning Faidah, SMA Negeri 1 Pasir Belengkong \\ ningfaidah@gmail.com \\ Harti, Universitas Negeri Surabaya \\ harti@unesa.ac.id \\ Waspodo Tjipto Subroto, Universitas Negeri Surabaya \\ waspodosubroto@unesa.ac.id
}

\begin{abstract}
ABSTRAK
Penelitian ini bertujuan untuk menganalisis pengaruh pengalaman ekonomi, kontrol diri dan pendapatan siswa SMA terhadap perilaku ekonomi SMA di Kecamatan Pasir Belengkong kabupaten Paser. Populasi penelitian ini adalah siswa kelas X dan XI SMA tahun 2016/2017. Teknik pengumpulan data menggunakan dokumentasi dan kuesioner/angket, metode proporsional random sampling. Hasil analisis menunjukkan bahwa secara parsial pendapatan siswa tidak berpengaruh signifikan terhadap perilakuan ekonomi sedangkan pengalaman ekonomi dan kontrol diri berpengaruh signifikan dan positif terhadap perilaku ekonomi siswa. Sedangkan secara simultan pengalaman ekonomi, kontrol diri dan pendapatan siswa berpengaruh signifikan terhadap perilaku ekonomi siswa. Pengaruh positif ditunjukkan dengan pemberian pengalaman ekonomi secara kontinu melalui pembiasaan dan adanya kontrol diri yang kuat dari setiap individu menentukan perilaku ekonomi rasional setiap siswa. Pembiasaan dalam sehari-hari terkait pengalaman ekonomi perlu ditingkat dan dalam penelitian selanjutnya kontrol informasi perlu ditambahkan.
\end{abstract}

Kata Kunci: Pengalaman Ekonomi, Kontrol Diri, Pendapatan Siswa, Perilaku Ekonomi.

\section{ABSTRACT}

This study aims to analyze the influence of economic experience, selfcontrol and income of high school students on the behavior of high school economics in Pasir Belengkong District Paser district. The population of this study are students of class X and XI High School year 2016/2017. Data collection techniques using documentation and questionnaire / questionnaire, the method of proportional random sampling. The result of the analysis shows that partially the student's income does not have significant effect on the economic performance while the economic experience and self-control have a significant and positive influence on the students' economic behavior. While simultaneous economic experience, self-control and student income have a significant effect on student economic behavior. Positive influence is indicated by the provision of 
continuous economic experience through habituation and strong selfcontrol of each individual determines the rational economic behavior of each student. Daily habits related to economic experience need to be improved and in subsequent research the control of information needs to be added.

Keywords: Economic Experience, Self Control, Student Income, Economic Behavior.

\section{PENDAHULUAN}

Perilaku ekonomi merupakan suatu tindakan yang dilakukan oleh setiap individu dalam kegiatan sehari-hari. McEachen (2001) mengartikan ekonomi sebagai ilmu yang mempelajari perilaku individu dan masyarakat dalam menentukan pilihan atau sumber daya langka dalam rangka meningkatkan kualitas hidupnya merupakan suatu perilaku ekonomi. Perilaku ekonomi siswa SMA di Kecamatan Pasir Belengkong ditunjukkan dengan tindakan konsumsi dan produksi disamping sekolah. Kegiatan konsumsi yang dilakukan siswa meliputi 95\% konsumsi akan baju sekolah, 50\% konsumsi akan buku sekolah, 98\% iuran kelas dan 60\% siswa melakukan infak. Konsumsi kebutuhan lain termasuk asesories, baju, hp, dan kesenangan lainnya. Selain itu dari seluruh siswa terdapat $42 \%$ siswa melakukan produksi dengan melakukan jualan on line dan membuat makanan untuk dititipkan dikantin sekolah. Proporsional perilaku ekonomi yang dilakukan siswa SMA terdapat kecenderungan mengutamakan keinginan daripada kebutuhannya. Masyarakat Pasir Belengkong mayoritas sebagai petani sawit yang memungkinkan siswa untuk ikut dalam kegiatannya. Hal ini mengarahkan siswa untuk dapat bertanggungjawab dalam perilakunya. Pengamatan selama mengajar di SMA Pasir Belengkong menunjukkan bahwa siswa SMA dalam melakukan perilaku ekonomi kurang menggunakan skala prioritas. Kecenderungan untuk menggunakan pendapatannya tanpa mempertimbangkan orientasi masa depan. Sehingga pada saat siswa dihadapkan pada kebutuhan keuangan dikelas XII $80 \%$ siswa mengalami keterbatasan dana dan mereka akan kebingungan karena tidak mempunyai simpanan yang bisa digunakan. Padahal pendapatan siswa tidak hanya berasal dari uang saku saja tetapi juga adanya bantuan pemerintah untuk bisa digunakan pada saatnya. Dari jumlah siswa 420 orang di SMAN 1 Pasir Belengkong 90\% siswa menerima uang lebih dari kebutuhannya. Sedangkan siswa yang memperoleh bantuan dari pemerintah dalam bentuk seperti BSM, Indonesia pintar, Kaltim cemerlang Paser Kemilau dan bantuan BAZ sebanyak 50\% dari jumlah siswa. Sedangkan $15 \%$ siswa anak dari orang tua berstatus pegawai negeri sipil dan 35\% adalah orang tua dengan bekerja sebagai pemilik perkebunan sawit dengan penghasilan lebih dari Rp. 10.000.000,'per bulan. Orang tua pada umumnya memberikan uang saku dalam bentuk bulanan begitu juga dengan beasiswa oleh pemerintah setiap enam bulan sekali. Hal ini sebenarnya merupakan suatu pembelajaran akan pengelolaan keuangannya sendiri secara mandiri.

Pengalaman ekonomi merupakan bentuk hasil sosialisasi oleh agen sosialisasi memberi peran penting dalam menentukan perilaku ekonomi. Miller dan Yung (1990) menyebutkan bahwa pemberian pengalaman ekonomi 
dilakukan dalam bentuk pemberian uang saku mulai dari masa anak-anak. Pemberian uang saku merupakan bentuk pelatihan tanggungjawab atas keuangan yang dimilikinya. Beutler dan Dickson (2008) menyebutkan bahwa pemberian sosialisasi ekonomi berdampak pada perilaku ekonomi remaja. Pengalaman sebagai salah satu faktor perilaku ekonomi seseorang berasal dari sosialisasi yang dilakukan oleh agen sosialisasi. Faktor internal yang mempengaruhi pengalaman ekonomi adalah kontrol diri yang merupakan pengendalian diri atas segala sesuatu yang akan dilakukan. William (2007) menyebutkan bahwa remaja mengadakan penginternalisasian moral yaitu melalui tingkah laku moral yang kemudian oleh tanggungjawab batin sendiri karena menjadi remaja berarti mengerti nilai-nilai, mengerti tidak hanya memperoleh pengertian saja, melainkan juga dapat menjalankan atau mengamalkannya. Siswa SMA sebagai remaja dalam perkembangan psikologinya masih sering lupa akan masa depannya (Firmansyah, 2014). Hal ini terbukti dari penelitian Nurasiyah (2010) menunjukkan bahwa di kota Bandung siswa mengelurkan uang sebanyak 61\% untuk jajan dan hanya 1,51\% saja yang digunakan untuk menabung. Padahal Nababan dan Sadalia (2013) menjelaskan bahwa siswa SMA adalah salah satu komponen masyarakat yang akan memberi pengaruh cukup besar terhadap perekonomian.

Pengalaman merupakan guru yang paling utama. Pengalaman dapat diartikan juga sebagai memori episodic yaitu memori yang menerima dan menyimpan peristiwa yang terjadi atau dialami individu pada waktu dan tempat tertentu, yang berfungsi sebagai referensi otobiografi. Anderson (2007) menjelaskan bahwa dalam kerucut pengalaman (Cole's of Experience) memberikan suatu hasil secara langsung dari suatu pengalaman konkrit, kenyataan yang ada dilingkungan kehidupan seseorang sampai kepada lambang (abstrak) saja. Hal ini menjelaskan bahwa dalam kerucut pengalaman tersebut semakin keatas puncak kerucut semakin abstrak pengalaman yang diperolehnya, artinya dalam proses memperoleh pengalaman seseorang tidak mengalami langsung tetapi hanya melalui abstrak saja.

Pengalaman langsung merupakan pengalaman yang diperoleh dengan melibatkan indera penglihatan, pendengaran, perasaan, penciuman, dan peraba (Syah, 2003). Perolehan pengalaman dari seseorang diartikan sebagai hasil sosialisasi dari agen sosialisasi. Menurut Cooley dalam Sunarto (2004) menjelaskan akan teorinya bahwa seseorang akan melihat pantulan dirinya berdasarkan apa yang dipikirkan orang lain terhadap dirinya dan kemudian pantulan yang ia terima tersebut akan dipantulkan lagi menjadi bagaimana caranya bersikap. Hal ini menunjukkan bahwa apa yang dialami atau diterima akan menjadi bagian dari diri individu. Koentjaraningrat (2008) menjelaskan bahwa sosialisasi merupakan seluruh proses di mana seorang individu sejak masa kanak-kanak sampai dewasa, berkembang, berhubungan, mengenal, dan menyesuaikan diri dengan individu-individu lain yang hidup dalam masyarakat sekitarnya. Artinya bahwa sosialisasi adalah proses berkembangkan seseorang dengan lingkungan yang ada disekitarnya. Sedangkan Shadly (1993) menjelaskan bahwa sosialisasi adalah proses di mana seseorang mulai menerima dan menyesuaikan diri terhadap adat istiadat suatu golongan. Hal ini menunjukkan bahwa sesuai dengan perkembangannya seseorang akan merasa bagian dari golongan tersebut. 
Menurut Luckmann (2012) tahapan sosialisasi dibedakan menjadi dua macam yakni sosialisasi primer dan sosialisasi sekunder. Sosialisasi primer sebagai sosialisasi pertama yang dijalani individu semasa kecil dengan belajar menjadi anggota masyarakat atau keluarga. Sosialisasi primer berlangsung saat anak berusia 1-5 tahun atau saat anak belum masuk ke sekolah. Anak mulai mengenal anggota keluarga dan lingkungan keluarga. Secara bertahap dia mulai mampu membedakan dirinya dengan orang lain di sekitar keluarganya. Sosialisasi sekunder adalah suatu proses sosialisasi lanjutan setelah sosialisasi primer yang memperkenalkan individu ke dalam kelompok tertentu dalam masyarakat. Berdasarkan pengertian diatas menunjukkan bahwa sosialisasi dalam setiap individu terjadi dalam dua tahapan yang berdasarkan usia yakni usia balita dan usia pasca balita. Sosialisasi dapat diperoleh dari berbagai sumber yang dikenal dengan agen sosialisasi. Nasution (2009) menyebutkan agen sosialisasi terdiri dari tiga keluarga, sekolah, dan masyarakat.

Menurut Pine dan Gilmora (1999) bahwa experience economic sebenarnya diajukan sebagai teori akan kemajuan ekonomi yang menjelaskan bahwa manusia bergerak melalui beberapa tahapan yang berbeda dari ekonomi agraris menjadi ekonomi industry. Hal ini dijelaskan bahwa kekuatan ekonomi akan melibatkan usaha memberikan pengalaman ekonomi pada pelanggan sebagai kenangan yang signifikan dan dapat membina hubungan jangka panjang yang lebih baik sehingga membawa kemajuan atau nilai. Brooks (2011) menjelaskan experience economy adalah perubahan manset dari materialism menjadi value, yang berarti kwalitas hidup tidak harus ditingkatkan dengan banyak kekayaan tetapi dengan penghematan sumber daya. Berdasarkan dari ulasan tersebut nampak bahwa experience economy merupakan penghematan sumber daya dalam memenuhi kebutuhan.

Pengalaman ekonomi sebagai hasil sosialisasi ekonomi yang dilakukan oleh keluarga, sekolah dan masyarakat akan membentuk pengalaman ekonomi pada anak-anak sehingga akan mampu mengendalikan diri untuk lebih fokus pada konsekuensi masa depan atas tindakan mereka sebagai remaja (Mischel, Shoda, dan Rodriguez, 1992). Menurut Miller dan Yung (1990) bahwa pengalaman ekonomi diperoleh melalui agen sosialisasi dapat dilakukan dengan sistem pemberian uang saku, dimana uang saku tidak tergantung pada melakukan pekerjaan rumah tangga atau mematuhi peraturan. Hal ini dipertegas oleh Webley et al (2012) bahwa dalam memberikan pengalaman ekonomi pada tiap generasi dan keadaan berbeda-beda, tergantung dari faktor yang mempengaruhi. Pada saat pengalaman ekonomi yang berkaitan penyediaan makanan, konsumsi, hiburan dapat dilakukan oleh orang tua (keluarga). Namun apabila itu sudah berkaitan dengan sosial ekonomi, pengalaman ekonomi diberikan oleh agen sosialisasi yang lain seperti internet, bank, dan televisi. Menurut Webley et al (2013) menjelaskan dalam mengukur sosialisasi ekonomi sebagai agen variabel pengalaman ekonomi menggunakan enam pertanyaan dengan empat pilihan jawaban atas intensitasnya berkaitan dengan penerimaan pendapatan pada usia 8-12 tahun dalam bentuk regular dan untuk disisihkan, melakukan sedikit pekerjaan rumah (seperti mencuci mobil), penggunaan uang dalam keseharian, melakukan pekerjaan sampingan diluar sekolah, pendidikan orang tua untuk mengajarkan membuat anggaran da terkait 
dan dorongan orang tua atau sekolah untuk menyimpan uang. . Adapun indikator pengalaman ekonomi terdiri atas intensitasnya berkaitan dengan penerimaan pendapatan pada usia 8-12 tahun dalam bentuk regular dan untuk disisihkan, melakukan sedikit pekerjaan rumah (seperti mencuci mobil), penggunaan uang dalam keseharian, melakukan pekerjaan sampingan diluar sekolah, pendidikan orang tua untuk mengajarkan membuat anggaran da terkait dan dorongan orang tua atau sekolah untuk menyimpan uang.

Kontrol diri terkait dengan pengendalian diri, Kontrol diri terkait erat dengan pengendalian diri. Tanhney (2004) menjelaskan bahwa kontrol diri sebagai kemampuan individu untuk menentukan perilakunya berdasarkan standart tertentu seperti moral, nilai, dan aturan di masyarakat agar mengarah pada perilaku positif. Hal ini menunjukkan bahwa kontrol diri didasarkan pada aturan yang ada dalam masayarakat. Imam (2013) pengendalian diri dan lebih peduli dengan kepuasan, hal ini akan lebih muda dan lebih mungkin untuk terlibat dalam perilaku berisiko untuk mengejar kesenangan. Alwisol (2009) tingkah laku disebabkan dan dipengaruhi oleh variabel eksternal, namun betapapun kuatnya stimulus dan penguat eksternal, manusia dapat mengubahnya memakai proses kontrol diri. Kekuatan pengaruh eksternal terhadap kontrol diri seseorang akan membentuk suatu karakter dalam diri seseorang yang akan menjadi suatu Kontrol diri. Nofziger (2005) menyatakan bahwa kontrol diri sebagai perlawanan terhadap godan pada saat ini yang mungkin merintangi cita-cita jangka panjang, menunda kesenangan atau tujuan lain. Newman (2008) kontrol diri sebagai kemampuan untuk memenui keinginan dengan memodifikasi perilaku sesuai dengan situasi, menyegerakan, atau menunda pekerjaan, dan berperilaku yang diterima secara sosial tanpa dibimbing atau diarahkan oleh hal lainnya.

Kontrol diri sebagai pengendalian atau kontrol terhadap diri pribadi dapat mewujudkan pemilihan tindakan dengan menggunakan skala prioritas. Dayakisni dan Hudaniah (2003) menjelaskan bahwa kontrol diri yang digunakan seseorang dalam menghadapi situasi tertentu terdiri atas Behavioral control (kontrol perilaku) kemampuan untuk mempengaruhi atau memodifikasi suatu keadaan yang tidak menyenangkan. Cognitive control (kontrol pengetahuan) kemampuan individu dalam mengolah informasi yang tidak diinginkan dengan cara menginterpretasi, menilai dan menggabungkan suatu kejadian dalam sutu kerangka kognitif sebagai adaptasi psikologis atau untuk mengurangi tekanan, Decision control (kontrol keptusan) kemampuan seseorang untuk memilih suatu tindakan berdasarkan pada sesuatu yang diyakini atau disetujuinya. Informational control (kontrol informasi) merupakan kesempatan untuk mendapatkan informasi mengenai kejadian yang menekan, kapan akan terjadi, mengapa terjadi dan apa konsekuensinya. Kontrol informasi ini dapat membantu meningkatkan kemampuan seseorang dalam memprediksi dan mempersiapkan yang akan terjadi dan mengurangi ketakutan seseorang dalam menghadapi sesuatu yang tidak diketahui, sehingga dapat mengurangi stress dan Retrospective control, merupakan kemampuan untuk menyinggung tentang kepercayaan mengenai apa atau siapa yang menyebabkan sebuah peristiwa yang menekan setelah hal tersebut terjadi. Individu berusaha mencari makna dari setiap peristiwa yang terjadi dalam kehidupan. Hal ini bukan berarti individu mengontrol setiap peristiwa yang 
terjadi, namun individu berusaha memodifikasi pengalaman stress tersebut untuk mengurangi kecemasan.

Berdasarkan dari penjelasan di atas bahwa makna kontrol diri terdiri atas kontrol perilaku, kontrol pengetahuan, kontrol keputusan, kontrol informasi dan kontrol retrospektif. Senada dengan hal tersebut Ghufron dan Risnawita (2013) menyebutkan bahwa kontrol diri terdiri atas tiga aspek yaitu kontrol perilaku (Behavior control), Kontrol Kognitif (Cognitive Control) dan Mengontrol Keputusan (Decisional Control). Menurut Hurlock (2002) bahwa kontrol diri berkaitan dengan emosi yakni sebagai pengendalian emosi yang akan membawa dampak pada sosial. Kontrol diri terkait erat dengan pengendalian diri. Tanhney (2004) menjelaskan bahwa kontrol diri sebagai kemampuan individu untuk menentukan perilakunya berdasarkan standart tertentu seperti moral, nilai, dan aturan di masyarakat agar mengarah pada perilaku positif. Hal ini menunjukkan bahwa kontrol diri didasarkan pada aturan yang ada dalam masayarakat. Imam (2013) ciri orang yang tidak memiliki pengendalian diri dan lebih peduli dengan kepuasan, hal ini akan lebih muda dan lebih mungkin untuk terlibat dalam perilaku berisiko untuk mengejar kesenangan. Lebih lanjut Alwisol (2009) tingkah laku disebabkan dan dipengaruhi oleh variabel eksternal, namun betapapun kuatnya stimulus dan penguat eksternal, manusia dapat mengubahnya memakai proses kontrol diri. Kekuatan pengaruh eksternal terhadap control diri seseorang akan membentuk suatu karakter dalam diri seseorang yang akan menjadi suatu Kontrol diri. Nofziger (2005) menyatakan bahwa kontrol diri sebagai perlawanan terhadap godaan pada saat ini yang mungkin merintangi cita-cita jangka panjang, menunda kesenangan atau tujuan lain. Newman (2008) menyatakan bahwa kontrol diri sebagai kemampuan untuk memenui keinginan dengan memodifikasi perilaku sesuai dengan situasi, menyegerakan, atau menunda pekerjaan, dan berperilaku yang diterima secara sosial tanpa dibimbing atau diarahkan oleh hal lainnya. Adapun indikator kontrol diri terdiri atas kontrol perilaku, kontrol pengetahuan dan kontrol keputusan.

Setiap individu melakukan kegiatan ekonomi baik berupa konsumsi maupun produksi. Dalam kegiatan ekonomi individu terdapat adanya penerimaan dan pengeluaran yang akan digunakan dalam kegiatan ekonominya. Siswa sebagai bagian dari individu yang melakukan kegiatan ekonomi dapat dipastikan memperoleh pendapatan dan melakukan pengeluaran baik berupa konsumsi maupun tabungan. Pendapatan yang diperoleh siswa bisa berasal dari uang saku, insentive pemerintah, dan hasil kerja paruh waktunya. Mankiw (2006) menjelaskan bahwa pendapatan adalah penghasilan yang diterima oleh rumah tangga dan usaha yang bukan perusahaan. Sedangkan menurut Boediono (2001) menyatakan bahwa pendapatan adalah sesuatu yang diterima oleh seseorang dapat berasal dari hasil penjualan faktor-faktor produksi yang dimiliki kepada sektor produksi. Friedman (dalam Skousen, 2001) membagi pendapatan menjadi pendapatan sementara dan pendapatan permanen. Pendapatan permanen merupakan rata-rata tingkat pendapatan yang berasal dari gaji dan non gaji yang diharapkan dalam jangka panjang. Selain itu pendapatan permanen memberi pengaruh terhadap konsumsi atau rata-rata kecenderungan konsumsi. Sehingga dapat dikatakan bahwa konsumsi mempunyai hubungan proporsional dengan pendapatan permanen. Sedangkan 
pendapatan sementara merupakan pendapatan yang diterima dari sumber dengan nilai yang berbeda dan tidak menentu.

Disponsibel Income (Yd) merupakan pendapatan bebas, Yp adalah pendapatan permananen dan $\mathrm{Yt}$ merupakan yeald transitory (pendapatan sementara). Teori pendapatan yang dikemukan oleh James (dalam Rahardja dan Manurung, 2004) mengatakan bahwa ketika pendapatan seseorang mengalami peningkatan maka dalam jangka pendek seseorang tersebut tidak secara langsung menaikkan pengeluaran konsumsi secara proporsional akibat kenaikan pendapatannya. Hal ini dikarenakan seseorang tersebut lebih memilih untuk menambah jumlah tabungan dan sebaliknya jika pendapatan berkurang maka seseorang tersebut tidak banyak mengurangi konsumsinya tetapi akan mengurangi tabungan yang dimilikinya. Berdasarkan Keynes (dalam Mankiw, 2006) menyebutkan bahwa penentu utama besarnya tabungan yang dilakukan oleh rumah tangga tergantung pada besar kecilnya pendapatan rumah tangga. Semakin besar pendapatan yang diterima oleh rumah tangga semakin besar pula tabungannya.

Pendapatan siswa yang bersumber dari uang saku merupakan ssesuatu yang diterima atau dipercaya masyarakat sebagai alat pembayaran atau transaksi. Uang dapat berupa uang kartal maupun uang giral. Sedangkan uang kartal adalah uang dalam bentuk uang kertas dan uang logam yang banyak berredar dimasyarakat. Karim (2010) menjelaskan bahwa uang adalah alat yang dapat membantu manusia dalam pemenuhan kebutuhan ekonomi. Dalam penelitian ini persepsi pendapatan siswa adalah pendapatan yang bersumber dari uang saku atau yang lain yang diberikan oleh orang tua atau dewasa (dalam hal siapapun) kepada remaja usia sekolah yang pengalokasiannya digunakan untuk keperluan jajan dan untuk ditabung. Berdasarkan pengertian tersebut ada beberapa catatan yang membedakan uang saku dengan uang yang lain, diantaranya sebagai berikut. (a) Uang saku diberikan oleh orang tua atau dewasa, (b) Uang saku diberikan untuk dialokasikan guna memenuhi kebutuhan jajan/simpanan dan (c) Uang saku biasanya diberikan ketika mau berangkat sekolah atau kegiatan yang lain (Dodo, 2008).

Senduk (2012) menyebutkan bahwa pemberian uang saku antara satu siswa dengan siswa lain berbeda tergantung dari kemampuan orang tua dan disesuaikan dengan tingkat usia dan penggunaanya untuk kebutuhan anak, keperluan siswa, jarak tempuh kesekolah. Sejalan dengan Novita (2013) menyebutkan bahwa pemberian uang saku justru mengajarkan prinsip bahwa uang saku tidak sama dengan uang jajan. Uang saku bisa digunakan untuk jajan, menabung, dan bersedekah. Artinya, anak-anak diajarkan untuk mengontrol dan tidak menghabiskan uang sakunya. Menurut Godo (dalam Setyanti, 2014) menyarankan sebaiknya pemberian uang saku dilakukan secara bertahap. Usia SD uang saku diberikan harian, usia SMP secara mingguan, dan SMA sampai kuliah diberikan bulanan. Selain itu uang saku memiliki komponen untuk dibelanjakan (uang jajan), uang untuk ditabung dan uang untuk didermakan. Besarnya uang jajan anak ini disesuaikan dengan standar hidup keluarga dan kebutuhanya. Selain itu melebihkan sekitar 20-30 persen untuk digunakan sebagai alokasi dana tabungan dan juga untuk aksi sosial di sekolah anak. Pengukuran variabel pendapatan siswa dalam penelitian ini menggunakan indikator sumber pendapatan, pengelolaan pendapatan, dan 
waktu pemberian (Dodo, 2008). Indikator pendapatan siswa meliputi sumber pendapatan, pengelolaan pendapatan dan waktu pemberian.

Tindakan atau aktivitas setiap individu baik secara sadar maupun tanpa disadari akan membentuk suatu perilaku. Pengertian perilaku mempunyai makna yang luas. Notoatmodjo (2003) menjelaskan bahwa perilaku merupakan tindakan atau aktivitas dari manusia itu sendiri yang mempunyai bentangan yang sangat luas, seperti berjalan, berbicara, bekerja, dan makan baik yang diamati langsung maupun yang tidak diamati langsung oleh pihak luar. Menurut Moefad (2007) perilaku itu terjadi karena adanya dorongan-dorongan yang kuat dari diri dalam diri seseorang itu sendiri yang difikirkan, dipercayai dan apa yang di rasakan, dorongan-dorongan itu yang di sebut motivasi. Menurut Skinner (2004) mengartikan perilaku sebagai respon atau reaksi seseorang terhadap stimulus. Dari pengertian tersebut dapat disimpulkan bahwa perilaku merupakan suatu aktivitas manusia sebagai reaksi dari stimulus baik diamati langsung maupun yang tidak langsung.

Dalam teori Skinner (2004) perilaku manusia berdasarkan teori Stimulus, Organisme, Respon (SOR) dikelompokkan menjadi dua yakni perilaku Tertutup (Cover Behavior) dan perilaku terbuka (Observable behavior). Goodwin (2012) Semua perilaku ekonomi merupakan perilaku manusia. Artinya setiap individu merupakan pelaku ekonomi yang akan berperilaku ekonomi dalam kegiatannya sehari-hari. Knight (dalam Scoot, 2010) menjelaskan bahwa perilaku ekonomi terkait dengan resiko dan ketidakpastian. Resiko merupakan kondisi dimana imbalan dan probabilitas atas kejadian dimasa depan dapat diketahui. Sedangkan ketidakpastian adalah kondisi dimana imbalan dan probablitas akan kejadian dimasa depan tidak dapat diketahui. Dalam teori Knight dijelaskan bahwa perilaku manusia yang berkaitan dengan ekonomi dalam memilih mempertimbangkan Value jedgement (keputusan nilai) atau valuation (penilaian). Sehingga dapat disimpulkan bahwa perilaku ekonomi dari pendapat Knight mengandung indikator keputusan nilai dan penilaian.

Menurut Arif (2009) disebutkan bahwa dalam pandangan neoklasik perilaku ekonomi mengarah pada individu sebagai homo economicus yang berarti setiap individu selalu digerakkan semata-mata oleh kepentingan pribadi atau motifnya untuk mendapatkan kepuasan dan keuntungan. Dalam teori Keynes menyebutkan akan teori utility dengan menitik beratkan pada bagaimana keputusan seharusnya diambil dalam situasi yang tidak menentu (prescriptive approach) dengan asumsi-asumsi well informed, instrumental rasionality, dan self interested. Maksud dari ketiga asumsi tersebut adalah memiliki informasi yang baik untuk memperhitungkan untung rugi, bersifat rasional untuk mementingkan keuntungan diri sendiri dan melakukan pertukaran dalam upaya memberikan hasil yang sebesar-besarnya dengan pengorbanan yang sekecil-kecilnya. Kahneman (2003) bahwa perilaku ekonomi merupakan kegiatan atau aktivitas seseorang secara sadar dalam memenuhi kebutuhan hidupnya berdasarkan prinsip ekonomi .yang sering disebut dengan teori ketidakpastian (uncertainty) yang dikenal dengan teori prospek (prospect theory) yang berfokus tentang bagaimana keputusan nyata itu diambil (descriptive approach). Adapun prinsip teori prospect yang dikembangkan oleh Kahneman dalam Yunus (2014) terdiri atas (a) Fungsi nilai 
(value function), dimana nilai dalam kerangka kerja bipolar terletak diantara perolehan (gains) dan kehilangan (losses). Fungsi nilai dari suatu perolehan (mendapatkan sesuatu) akan berbeda dengan kehilangan sesuatu. Value kehilangan sesuatu dibobot lebih tinggi dibandingkan value perolehan walaupun nilai nominalnya sama. (b) Pembingkaian (framing), teori prospek melihat bahwa preferensi akan tergantung pada bagaimana suatu persoalan dibingkai atau diformulasikan. Frame yang diadopsi kemudian ditentukan oleh formulasi masalah yang dihadapi, norma, dan kebiasaan, serta karakteristik para pengambil keputusan. (c) Perhitungan psikologis disebut juga dengan perhitungan mental yakni asumsi bahwa pengambilan keputusan oleh manusia tidak hanya bembingkai dari pilihan-pilihan yang ditawarkan, tetapi juga membingkai hasil serta akibat dari suatu pilihan. (d) Probabilitas, dalam teori prospek melihat kecenderungan pengambilan keputusan manusia adalah fungsi dari bobot keputusan (decition weight) itu sendiri. dan (e) Efek kepastian, yang mana teori prospek memprediksipilihan tanpa resiko sama sekali akan lebih disukai dibanding pilihan yang masih beresiko meski kemungkinannya sangat kecil

Kelima prinsip di atas menjelaskan bahwa dalam teori prospek menunjukkan bahwa orang akan memiliki kecenderungan irasional untuk lebih enggan mempertaruhkan keuntungan (gain) daripada kerugian (loss). Teori prospek menunjukkan bahwa orang menghargai kerugian dan keuntungan dalam sudut pandang yang berbeda. Selain itu dapat dijelaskan bahwa perilaku ekonomi merupakan suatu tindakan atau aktivitas dalam memenuhi kebutuhan dengan menggunakan prinsip-prinsip ekonomi yang sesuai. Dalam melakukan pengukuran tentang perilaku ekonomi digunakan beberapa indikator yang sesuai dengan keadaan obyek diteliti. Adapun indikator yang digunakan dalam variabel perilaku ekonomi mengarah pada pendapat Kahneman, namun untuk pertimbangan frame tidak digunakan karena obyek yang diteliti adalah siswa SMA yang belum mampu membingkai atas suatu keputusan, mereka cenderung pada pemenuhan kebutuhan dan kesenangan. Adapun indikator perilaku ekonomi yang digunakan dalam penelitian ini terdiri atas mempertimbangkan fungsi nilai dalam mengambil keputusan, memperhitungkan psikologis (mental), menentukan Probabilitas atas apa yang dilakukan, dan mempertimbangkan efek kepastian.

Penelitian ini mengkaji hubungan antara tiga variabel bebas dan satu variabel terikat. Pengalaman ekonomi merupakan peristiwa yang benar-benar dialami sebagai hasil sosialisasi yang dilakukan oleh keluarga, sekolah dan masyarakat. Pengalaman ekonomi pada anak-anak akan mampu menunda gratifikation pada usia selanjutnya sebagai latihan untuk bisa mengendalikan dirinya untuk lebih focus pada konsekuensi masa depan atas tindakan mereka sebagai remaja (Mischel, Shoda, dan Rodriguez, 1992). Hal ini menunjukkan bahwa seseorang yang mempunyai pengalaman ekonomi pada usia anak-anak akan berperilaku ekonomi yang rasional pada usia selanjutnya.

Webly dan Ellen (2013) menyebutkan bahwa "economic socialization, saving and assets in European young adults adalah economic socialization, personality characteristics or dispositions, assets and income, and general money management. Maksud penelitian ini adalah faktor yang menentukan perilaku ekonomi anak muda di Eropa adalah pengalaman ekonomi sebagai 
hasil sosialisasi ekonomi yang membentuk karakter individu dalam meningkatkan kekayaan dan pendapatan serta mengatur keuangannya oleh generasi muda. Pengalaman ekononomi sebagai hasil sosialisasi ekonomi yang dilakukan oleh orang sekitar yang berkaitan dengan pembiasaan, pengelolaan, tanggungjawab, penganggaran dan dorongan akan menentukan karakter seseorang. Teori perilaku terencana menurut Ajzen (2005) menjelaskan bahwa secara spesifik, dalam planned behavior theory intensi untuk melakukan suatu perilaku adalah indikasi kecenderungan individu untuk melakukan suatu perilaku dan merupakan anteseden langsung dari perilaku tersebut. Intensi untuk melakukan suatu perilaku dapat diukur melalui tiga prediktor utama yang memengaruhi intensi tersebut, yaitu attitude toward the behavior, subjective norm, dan perceived behavioral control. Hal ini menunjukkan bahwa perilaku seseorang dikembangkan dari pengalaman yang terjadi sebelumnya dari lingkungan disekitar mereka sehingga akan menetapkan tingkat harapan, terhadap sikap dan perilaku.

Schuchardt et al (2009) menjelaskan bahwa pentingnya peran orang tua dan lingkungan keluarga untuk proses sosialisasi anak didaerah pribadi (keluarga), telah didokumentasikan dengan baik. Artinya bahwa keluarga sebagai agen sosialisasi utama akan membentuk pengalaman dasar bagi diri seseorang. Gudono dan Hartadi (1998) menyebutkan bahwa hubungan pengalaman ekonomi dengan perilaku ekonomi pada teori prospek sebagai acuan tidak cocok digunakan di Indonesia terutama untuk rasionalitas, karena adanya perbedaan sosial dan budaya dengan negara Amerika dan Kanada sebagai tempat lahirnya teori prospek dalam perilaku ekonomi. Masyarakat Indonesia lebih bersifat konsisten dalam memandang nilai nominal uang, sehingga lebih risk neutral. Hal ini berarti pada indikator rasionalitas tidak ada hubungannya dengan perilaku ekonomi.

Haryanto (2006) dalam penelitiannya dengan subyek mahasiswa S1 menyebutkan dalam penelitiannya teori prospek dan pembuatan keputusan menunjukkan bahwa pengalaman ekonomi akan mempengaruhi dalam pengambilan keputusan dengan menggunakan teori prospek karena masyarakat sudah mulai mengabaikan konsistensi terhadap nilai rupiah. Hal ini karena masyarakat Indonesia telah mengalami beberapa ketidakpastian akan ekonomi. Penelitihan Beutler dan Dickson (2008) mengatakan bahwa meskipun literature dari adanya pengaruh pengalaman ekonomi dengan perilaku ekonomi sangat terbatas namun adanya sosialisasi ekonomi sebagai agen pengalaman ekonomi mempunyai dampak terhadap perilaku ekonomi dan keuangan remaja dan dewasa. Hal ini ditunjukkan dengan remaja dan dewasa lebih mampu mengelola keuangannya setelah mereka mempunyai pengalaman ekonomi.

Kontrol diri sebagai salah satu faktor internal yang mempengaruhi perilaku ekonomi merupakan aktivitas yang mendorong seseorang untuk melakukan penghematan dengan menurunkan pembelian impulsive (Otto et al, 2004). Faktor yang berasal dari dalam diri sendiri yang mempunyai perang paling utama dalam mengontrol diri terhadap keuangan. Tanhney at al (2004) menjelaskan bahwa kedisiplinan yang merupakan kesadaran diri untuk mematuhi aturan serta kemampuan diri untuk menyesuaikan dirinya dengan perubahan, maka secara emplisit telah membentuk kontrol diri (self control). Karakter disiplin akan mendorong seseorang untuk mampu mengontrol dirinya 
dalam melakukan segala sesuatu. Self control pada umumnya berusaha untuk mencapai preferensi jangka panjang, menahan untuk membelanjakan keuangan sesuai dengan kebutuhan bukan keinginan. Mahdzan dan Tabiani (2013) yang menyebutkan bahwa demografi yang salah satunya adalah usia sangat mempengaruhi keputusan seseorang dalam menentukan perilaku sehari-hari baik saat ini maupun waktu yang akan datang. Menyisihkan uang sebesar 20$30 \%$ dari uang saku merupakan wujud dari preferensi jangka panjang. Nofzinger (2005) mengatakan bahwa seseorang mengontrol pengeluarannya dengan melawan keinginan-keinginan yang bukan kebutuhan. Dengan kata lain self control merupakan strategi oleh setiap individu untuk dapat melakukan kegiatan yang bersifat rasional dengan pertimbangan-pertimbangan dalam perilaku ekonomi.

Pendapatan siswa merupakan total perolehan yang berasal dari orang tua atau dewasa lain untuk digunakan sebagai uang jajan, menabung dan berderma. Pendapatan siswa berupa uang saku dari orang dewasa dan insentive dari pemerintah yang berupa bantuan atau beasiswa. Berdasarkan teori bahwa semakin tinggi pendapatan akan meningkatkan pengeluaran. Melihat hal tersebut pemanfaatan pendapatan dapat mendorong perilaku ekonomi yang bersifat rasional. Miller dan Yung (1990) menyebutkan bahwa dengan pendekatan uang saku menyiratkan lebih percaya antara orang tua dan anak, dan membuat anak untuk mampu menjalani kehidupan sebagai pelaku ekonomi. Artinya bahwa pemberian uang saku sebagai pendapatan siswa akan mempengaruhi perilaku siswa dalam kehidupannya terutama pada pengelolaan keuangannya.

Suryani (2005) dalam penelitiannya menyebutkan bahwa terdapat hubungan antara status ekonomi orang tua terhadap prestasi dan perilaku ekonomi anak. Melalui besar kecilnya pemberian uang saku terhadap anak mampu membentuk perilaku keuangannya dalam kehidupannya. Hal ini menunjukkan bahwa apabila status ekonomi orang tua baik, maka pemberian uang saku akan cenderung lebih tinggi dibanding yang status ekonominya kurang baik. Sehingga membawa pada perilaku ekonomi anak yang terarah sebagai dampak dari orang tuanya. Sedangkan Wahyono (2001) menyebutkan bahwa perilaku ekonomi dalam keluarga akan memberikan pengalaman ekonomi pada anak, dengan ditunjukkan dengan pemberian uang saku sebagai awal pendidikan ekonomi dalam keluarga. Hal ini mengisyaratkan bahwa uang saku sebagai bagian dari pendapatan siswa akan mempengaruhi perilaku ekonomi siswa. Berdasarkan penelitian di atas menunjukkan bahwa pemberian uang saku sebagai pendapatan siswa atau anak sekolah sebagai bentuk pemberian pengalaman dalam pengelolaan ekonomi terutama berkaitan dengan keuangan. Status sosial orang tua juga mempengaruhi perilaku ekonomi anak melalui besar kecilnya pemberian uang saku.

Pengalaman ekonomi dikatakan berpengaruh terhadap perilaku ekonomi mengarah pada segala sesuatu yang dialami, didengar, dilihat akan berpengaruh terhadap perilaku seseorang dalam kehidupan sehari-hari. Pengalaman ekonomi seseorang akan terbentuk mulai pada masa anak-anak melalui agen sosialisasi keluarga. Segala sesuatu yang dilakukan oleh keluarga akan menjadi suatu pengalaman pada anak dan akan membentuk perilaku ekonomi. Perkembangan anak terus mengalami perubahan seiring dengan 
pertumbuhan usianya. Setelah masuk dalam usia sekolah dan bersosialisasi dengan masyarakat maka agen sosialisasi tidak terbatas pada keluarga tetapi sekolah, teman sebaya, televise, internet dan masyarakat.

Kontrol diri sebagai bagian dari faktor internal dalam perilaku ekonomi mempunyai pengaruh yang cukup besar, karena terkait dengan pengendalian diri seseorang. Kontrol diri yang kuat pada seseorang akan membentuk pengendalian untuk mampu bersikap rasional dalam kehidupan sehari-hari. Sikap rasional akan membentuk perilaku ekonomi yang sesuai dengan prinsip ekonomi yang berlaku. Kontrol diri seseorang terdiri atas kontrol perilaku, kontrol pengetahuan, dan kontrol keputusan.

Perilaku ekonomi tidak dapat terlepas dari pendapatan seseorang, siswa sebagai bagian dari pelaku ekonomi yang mempunyai pendapatan bersumber dari pemberian orang dewasa yang digunakan sebagai uang jajan dan menabung akan berpengaruh terhadap perilaku ekonomi. Besarnya pendapatan siswa akan mendorong perilaku ekonomi, baik perilaku ekonomi rasional maupun non rasional dengan pertimbangan skala prioritas. Kapelliushnikov (2015) menjelakan bahwa perilaku mempunyai standar umum yang mendasari rekomendasi politik sebagai paternalistic, yang artinya dalam filsafat sosial dapat dipahami bahwa bentuk campur tangan pihak ketiga dalam kehidupan seseorang terhadap dirinya yakni (negara, keluarga, atau gereja) akan meningkatkan kesejahteraan dan atau tidak membiarkan dirinya berbahaya. Hal ini menunjukkan bahwa dalam perilaku ekonomi seseorang selain dipengaruhi oleh kontrol diri yang telah terbentuk dari karakter dirinya juga akan dipengaruhi oleh pihak ketiga terutama orang tua maupun negara (lingkungan sekitar) dengan istilah Paternalisme. Paternalisme melibatkan pemaksaan (membatasi kebebasan) yang bertujuan untuk meningkatkan kesejahteraan individu yang ditargetkan.

Berdasarkan latar belakang di atas penelitian bertujuan untuk menganalisis pengaruh pengalaman ekonomi terhadap perilaku ekonomi, kontrol diri terhadap perilaku ekonomi, pendapatan siswa terhadap perilaku ekonomi dan secara bersama-sama menganalisis pengaruh pendapatan siswa, kontrol diri, pendapatan siswa terhadap perilaku ekonomi siswa SMA di Kecamatan Pasir Belengkong.

\section{METODE PENELITIAN}

Pendekatan penelitian yang digunakan dalam penelitian ini adalah pendekatan kuantitatif yang digunakan untuk mendiskripsikan fakta-fakta atau karakteristik suatu populasi secara sistematis, faktual, dan akurat tentang pengaruh pengalaman ekonomi, kontrol diri dan pendapatan siswa terhadap perilaku ekonomi pada siswa SMA di Kecamatan Pasir Belengkong. Variabel dalam penelitian ini terdiri atas tiga variabel bebas pengalaman ekonomi $\left(\mathrm{X}_{1}\right)$, kontrol diri $\left(\mathrm{X}_{2}\right)$, dan pendapatan siswa $\left(\mathrm{X}_{3}\right)$ dan variabel terikat perilaku ekonomi (Y). Populasi dalam penelitian adalah sekolah yang ada di Kecamatan Pasir Belengkong dengan 226 siswa yang berasal dua sekolah. Teknik pengambilan sampel menggunakan random sampling dengan rumus Slovin sedang pengambilan perkelas mengambil proporsional random sampling diperoleh jumlah sampel 144 siswa. Setelah itu data diolah, ditafsirkan dan 
simpulkan dengan menggunakan analisa regresi linier berganda. Teknik pengumpulan data meliputi dokumentasi dan angket/quesioner.

\section{HASIL PENELITIAN DAN PEMBAHASAN}

Analisis dalam penelitian ini menggunakan analisis regresi yang berfungsi untuk mengetahui ada tidaknya pengaruh antara ketiga variabel bebas pengalaman ekonomi $\left(\mathrm{X}_{1}\right)$, kontrol diri $\left(\mathrm{X}_{2}\right)$, dan pendapatan siswa $\left(\mathrm{X}_{3}\right)$ terhadap variabel terikat perilaku ekonomi (Y). Persamaan regresi yang diperoleh $\mathrm{Y}=20.559+0,460 \mathrm{X}_{1}+0,331 \mathrm{X}_{2}+0,039 \mathrm{X}_{3}+$ ei. Berdasarkan persamaan tersebut dapat dijelaskan bahwa nilai konstan (a) yang dihasilkan sebesar 20.559, artinya jika variabel pengalaman ekonomi $\left(\mathrm{X}_{1}\right)$, Kontrol diri $\left(\mathrm{X}_{2}\right)$, dan pendapatan siswa $\left(\mathrm{X}_{3}\right)$ given maka perilaku ekonomi sebesar 20.559. Nilai koefisien regresi pada variabel pengalaman ekonomi $\mathrm{X}_{1}$ adalah 0,460 artinya setiap perubahan variabel pengalaman ekonomi X1 akan berpengaruh positif pada perilaku ekonomi (Y) sebesar 0,460 dengan asumsi variabel kontrol diri $\left(\mathrm{X}_{2}\right)$ dan variabel pendapatan siswa $\left(\mathrm{X}_{3}\right)$ given. Nilai koefisien bernilai positif menunjukkan pengaruh yang searah, artinya jika variabel pengalaman ekonomi $\left(\mathrm{X}_{1}\right)$ naik sebesar 1 satuan maka akan berpengaruh pada kenaikan perilaku ekonomi (Y) sebesar 0,460 satuan dan sebaliknya jika variabel pengalaman ekonomi turun satu satuan maka akan berpengaruh pada penurunan perilaku ekonomi (Y) sebesar 0,460 satuan. Nilai koefisien regresi pada variabel kontrol diri $\left(\mathrm{X}_{2}\right)$ adalah 0,331 artinya setiap perubahan variabel control diri $\left(\mathrm{X}_{2}\right)$ akan berpengaruh positif pada perilaku ekonomi $(\mathrm{Y})$ sebesar 0,331 dengan asumsi variabel pengalaman ekonomi $\left(\mathrm{X}_{1}\right)$ dan pendapatan siswa $\left(X_{3}\right)$ given. Nilai koefisien regresi bernilai positif menunjukkan pengaruh yang ditimbulkan searah artinya kenaikan satu satuan pada variabel control diri maka akan berpengaruh pada kenaikan perilaku ekonomi sebesar 0,331 satuan dan sebaliknya jika variabel kontrol diri $\left(\mathrm{X}_{2}\right)$ turun satu satuan maka akan berpengaruh pada turunnya perilaku ekonomi sebesar 0,331 satuan. Nilai koefisien regresi pada variabel pendapatan siswa $\left(\mathrm{X}_{3}\right)$ adalah sebesar 0,039 , artinya setiap perubahan variabel pendapatan siswa $\left(\mathrm{X}_{3}\right)$ akan berpengaruh positif pada perilaku ekonomi (Y) sebesar 0,039 dengan asumsi variabel pengalaman ekonomi $\left(\mathrm{X}_{1}\right)$, kontrol diri $\left(\mathrm{X}_{2}\right)$ given. Nilai koefisien regresi bernilai positif menunjukkan pengaruh yang searah antara variabel pendapatan siswa $\left(\mathrm{X}_{3}\right)$ dan perilaku ekonomi $(\mathrm{Y})$, artinya jika variabel pendapatan siswa $\left(\mathrm{X}_{3}\right)$ naik sebesar 1 satuan maka akan berpengaruh pada kenaikan perilaku ekonomi sebesar 0,039 satuan begitu pula sebaliknya. Penurunan pendapatan siswa $\left(\mathrm{X}_{3}\right)$ sebesar 1 satuan akan berpengaruh pada penurunan perilaku ekonomi sebesar 0,039 satuan. Hal tersebut memberikan pengaruh yang sangat kecil. Melihat hal tersebut dapat disimpulkan pendapatan siswa tidak berpengaruh terhadap perilaku ekonomi dikarenakan nilai koefisian kurang dari 0,05 .

Selanjutkan dilakukan uji untuk menentukan ada pengaruhnya secara parsial atau secara simultan. Uji F dilakukan untuk menguji pengaruh variabel pengalaman ekonomi, kontrol diri dan pendapatan siswa secara simultan terhadap perilaku ekonomi. Hasil uji $\mathrm{F}$ berdasarkan tabel uji ANOVA atau F

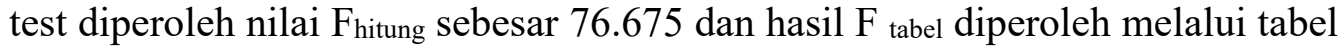


F dengan dfl (3) sebagai df pembilang dan df2 (140) sebagai df penyebut dengan taraf signifikan 0,05 , sehingga diperoleh nilai $F$ tabel sebesar 2,67. Maka nilai $\mathrm{F}_{\text {hitung }}>\mathrm{F}$ tabel $(76.675>2,67)$, maka $\mathrm{H}_{0}$ ditolak dan $\mathrm{H}_{\mathrm{a}}$ diterima. Sehingga dapat disimpulkan bahwa pengalaman ekonomi, kontrol diri dan pendapatan siswa secara simultan berpengaruh signifikan terhadap perilaku ekonomi siswa. Hal ini menunjukkan hipotesis dari penelitian ini terbukti kebenarannya.

Uji T digunakan untuk menguji hipotesis tentang koefisien slope regresi secara parsial (individual). Seberapa jauh pengaruh suatu variabel bebas secara parsial terhadap variabel terikat. Uji t dilakukan pada pengalaman ekonomi, kontrol diri, pendapatan siswa terhadap perilaku ekonomi. Variabel pengalaman ekonomi memiliki nilai thitung $=6.109$ dan nilai tabel $=1,656$ pada df 140 dengan tingkat signifikan sebesar 0,05. Hal ini menunjukkan bahwa thitung $>$ ttabel maka Ho ditolak dan Ha diterima, sehingga secara parsial pengalaman ekonomi berpengaruh signifikan terhadap perilaku ekonomi siswa SMA di Kecamatan Pasir Belengkong. Variabel kontrol diri memiliki nilai $t_{\text {thitung }}=6.531$ dan nilai tabel $=1,656$ dengan df 140 dengan tingkat signifikan sebesar 0,05 ,maka diperoleh hasil thitung $>t_{\text {tabel }}=6.531>1.656$. Hal ini menunjukkan bahwa kontrol diri berpengaruh secara signifikan terhadap perilaku ekonomi siswa SMA di Kecamatan Pasir Belengkong. Variabel pendapatan siswa memiliki nilai thitung $=0.963$ dan nilai tabel $=1,656$ pada $\mathrm{df}$ 140 dengan tingkat signifikan sebesar 0,05 . Berdasarkan hasil uji t terlihat bahwa thitung $<$ tabel maka Ho diterima dan Ha ditolak, sehingga secara parsial pendapatan siswa tidak berpengaruh signifikan terhadap perilaku ekonomi siswa SMA di Kecamatan Pasir Belengkong. Besarnya pengaruh variabel bebas terhadap variabel terikat, berdasarkan hasil uji determinasi ditunjukkan mealui besarnya adjusted $\mathrm{R}$ Square sebesar 0,614 yang mengandung arti $61,40 \%$ variasi perilaku ekonomi dapat dijelaskan oleh tiga variabel dependent yakni pengalaman ekonomi, kontrol diri dan pendapatan siswa. Sedangkan $38,60 \%$ dijelaskan oleh variabel lain yang tidak dimasukkan dalam penelitian ini.

Berdasarkan hasil pengujian hipotesis pertama diperoleh hasil yang menunjukkan bahwa pengalaman ekonomi berpengaruh positif terhadap perilaku ekonomi siswa SMA di Kecamatan Pasir Belengkong. Apabila siswa SMA sering menerima pengalaman ekonomi dari agen sosialisasi akan meningkatkan perilaku ekonomi yang rasional dikalangan siswa SMA di Kecamatan Pasir Belengkong. Pengalaman ekonomi yang dimiliki diterima mulai dari lingkungan keluarga, sekolah dan masyarakat membentuk suatu pengalaman ekonomi yang menentukan suatu perilaku ekonomi rasional. Begitu pula sebaliknya, apabila pengalaman ekonomi yang dimiliki siswa SMA di Kecamatan Pasir Belengkong kurang sebagai akibat kurang intensnya para agen sosialisai dalam memberikan pengalaman ekonomi maka perilaku ekonomi yang dilakukan siswa SMA di Kecamatan Pasir Belengkong juga akan berkurang.

Pengaruh positif yang ditimbulkan dari pengalaman ekonomi terhadap perilaku ekonomi siswa SMA di Kecamatan Pasir Belengkong ditunjukkan dengan hasil penelitian bahwa siswa sering memperoleh pengalamanpengalaman ekonomi dari agen sosialisasi keluarga, sekolah dan masyarakat. 
Pengalaman yang diberikan oleh agen sosialisasi secara kontinue mulai dari masa anak-anak sampai mereka duduk di SMA. Adapun pengalaman yang diberikan dalam bentuk pemberian uang saku secara regular dan disisihkannya, diajarkannya melakukan pekerjaan rumah sebagai bentuk tanggungjawab seperti mencuci piring, menyapu, mencuci motor/mobil, mencuci baju dan menyetlikanya, menggunakan uang dalam keseharian, melakukan pekerjaan sampingan di luar rumah, orang tua mengajarkan membuat anggaran dan bersama dengan pihak sekolah mendorongnya untuk menabung. Hal ini sesuai dengan pendapat penelitian Webley et al (2012) yang menyebutkan bahwa peran sosialisasi ekonomi yang dapat memberikan pengalaman ekonomi memainkan peran penting dalam pembentukan perilaku ekonomi pada orang dewasa muda oleh orang tua maupun lingkungan yang ada disekitarnya.

Hasil penelitian ini sesuai dengan teori Cooley dalam Sunarto (2004) yang menjelaskan bahwa seseorang akan melihat pantulan dirinya berdasarkan apa yang dipikirkan dari orang lain terhadap dirinya dan kemudian pantulan yang diterima tersebut akan dipantulkan lagi pada bagaimana caranya bersikap. Hal ini menunjukkan bahwa apabila seseorang telah mengalami atau melihat atas sesuatu maka akan digunakan dalam bagaimana seseorang untuk bersikap. Pie and Gilmora (2013) dalam teori pengalaman ekonomi bahwa pemberian kenangan akan suatu aktivitas sebagai pengalaman ekonomi secara signifikan pada seseorang akan dapat membentuk pembiasaan dalam jangka panjang yang lebih baik sehingga membawa kemajuan atau nilai. Apabila seseorang dengan pengalaman ekonomi yang rendah maka dalam kehidupan selanjutnya akan mempunyai perilaku ekonomi yang terbatas.

Selain itu hasil penelitian ini juga sesuai dengan penelitian Mischel, Shoda dan Rodriguez (1992), Schchardtet al \& Shim et al (2009), Webley et al (2013), dan Beutler dan Dickson (2008) yang menjelaskan bahwa variabel pengalaman ekonomi yang diperoleh sebagai hasil sosialisasi ekonomi oleh agen sosialisasi (keluarga, sekolah dan masyarakat) berpengaruh signifikan terhadap perilaku ekonomi siswa SMA di Kecamatan Pasir Belengkong. Pengalaman ekonomi merupakan faktor yang penting dalam pembentukan perilaku ekonomi seseorang. Hal ini nampak dari hasil penelitian yang menunjukkan setiap kenaikan pengalaman ekonomi seseorang akan meningkatkan perilaku ekonominya dimasa depannya. Namun hasil penelitian ini tidak sesuai dengan penelitian yang dilakukan oleh Gudono \& Hartadi (1998) yang menyebutkan bahwa hubungan pengalaman ekonomi dengan perilaku ekonomi pada teori prospek terutama rasionalitas sebagai acuan tidak signifikan, yang disebabkan karena perbedaan sosial dan budaya. Hal tersebut cukup beralasan, karena penelitian tersebut dilakukan sebelum masyarakat Indonesia mengalami tekanan-tekanan ekonomi .

Berdasarkan hasil ulasan di atas dapat disimpulkan bahwa hasil penelitian ini sesuai teori Brook (2011) yang menjelaskan bahwa pengalaman ekonomi seseorang terkait dengan perubahan manset dari materialism menjadi value yang berarti bahwa dalam upaya meningkatkan kesejahteraan tidak harus diukur dengan kekayaan tetapi dengan penghematan sumber daya.

Variabel dari kontrol diri dengan indikator kontrol pengetahuan, kontrol perilaku dan kontrol kepuasan rata-rata dihasilkan kriteria tinggi artinya bahwa kontrol diri berpengaruh terhadap perilaku ekonomi siswa SMA. Meskipun 
secara individu dalam indikator kontrol kepuasan dengan sub indikator mampu memilih tindakan berdasarkan apa yang diyakini individu mempunyai rata-rata rendah. Hal ini disebabkan usia siswa SMA dalam masa remaja awal yang mempunyai emosional yang labil. Sesuai dengan Maksum (2016) yang menyebutkan bahwa dalam perilaku remaja kontrol yang dilakukan tidak hanya dari diri sendiri tetapi harus tetap dalam kontrol orang tua atau orang dewasa. Hal ini disebabkan sikap remaja yang masih labil dalam perilaku ekonominya, yakni kecenderungan untuk memenuhi keinginan lebih tinggi dibandingkan dengan kebutuhan. Lingkungan sekitar juga memberi pengaruh yang besar dalam memberikan kontrol dalam perilaku remaja. Hasil penelitian ini sesuai dengan penelitian yang dilakukan oleh Otto et al (2004), Tanhney et al (2004) dan Nofzinger (2005) yang menyatakan bahwa secara parsial kontrol diri berpengaruh positif dan signifikan terhadap perilaku ekonomi. Hal ini dikarenakan kontrol diri yang semakin meningkat akan menyebabkan meningkatkan perilaku ekonomi yang rasional. Kontrol diri berkaitan dengan disipilin yang merujuk pada kesadaran diri untuk mematuhi aturan serta kemampuan diri untuk menyesuaikan dirinya dengan perubahan dan secara emplisit akan membentuk kontrol diri. Sedangkan karakter disiplin akan mendorong seseorang untuk mampu mengontrol dirinya dalam melakukan segala sesuatu. Selain itu seseorang mengontrol pengeluarannya dengan melawan keinginan-keinginan yang bukan kebutuhan. Dengan kata lain kontrol diri merupakan strategi oleh setiap individu untuk dapat melakukan kegiatan yang bersifat rasional sebagai perilaku ekonomi. Hal ini sejalan dengan penelitian Mahdzan dan Tabiani (2013) yang menyebutkan bahwa demografi yang salah satunya adalah usia sangat mempengaruhi keputusan seseorang dalam menentukan perilaku sehari-hari baik saat ini maupun waktu yang akan datang. Kematangan usia juga memberi peran dalam menentukan sikap kotrol diri terhadap perilaku individu.

Pendapatan siswa mempunyai nilai rata-rata sangat rendah. Hal ini disebabkan karena nilai dari pendapatan siswa terjadi rentan yang sangat jauh antara siswa satu dengan yang lainnya. Besar kecilnya pendapatan yang diperoleh oleh siswa rata-rata sangat rendah dibandingkan dengan nilai yang diperolehnya. Hal ini disebabkan oleh kesenjangan pendapatan orang tua siswa, sehingga mempengaruhi besar kecilnya pendapatan yang diperoleh oleh siswa. Pendapatan siswa bersumber dari uang saku yang diberikan oleh oleh tua atau dewasa lain. Hal ini bertentangan dengan pendapat Suryani (2005) dan wahyono (2001) yang menyatakan bahwa terdapat hubungan antara status ekonomi orang tua melalui besarnya uang saku terhadap prestasi dan perilaku ekonomi anak. Namun sesuai dengan pendapat Hurlock (2002) menyatakan bahwa perkembangan psikologi remaja ditandai dengan adanya rasa ingin bebas dalam mencari jati diri, mengindahkan untung rugi dalam mengelola pendapatannya. Artinya nilai pendapatan siswa tidak menentukan perilaku ekonomi siswa terutama untuk saat remaja, karena siswa SMA sebagai remaja berorientasi pada memenuhi kepuasan menentukan identitas diri. Kepuasaan dalam mencoba segala sesuatu dalam menunjukkan dirinya masih sangat dominan.

Pada indikator waktu pemberian pendapatan siswa menunjukkan rata-rata sedang dengan rata-rata responden memperoleh pendapatan secara dua 
mingguan. Pemberian pendapatan siswa yang bersumber dari uang saku secara bertahap merupakan bagian dari pembelajaran dalam pemberian tanggung jawab terhadap anak-anak, sekaligus sebagai upaya dalam pelatihan siswa dalam pemberian pengalaman ekonomi yang berkaitan dengan pengelolaan keuangan. Hal ini sesuai dengan penelitian Setyanti (2014) yang menjelaskan bahwa pendapatan siswa yang bersumber dari uang saku diberikan secara bertahan, SD secara harian, SMP secara mingguan dan SMA secara dua mingguan atau bulanan. Begitu pula dengan pendapat Santrock (2007) yang menyebutkan bahwa berdasarkan perkembangan psikologi remaja menyebutkan bahwa masa remaja adalah masa mencari jati diri artinya remaja memutuskan siapakah dirinya, apa keunikannya dan apa yang menjadi tujuan hidupnya. Dalam mengambil keputusan mengenahi pendapatan atau keuangannya siswa cenderung mengutamakan konsumsi kebutuhan yang tidak dipenuhi secara langsung oleh orang tua dan dilanjutkan konsumsi kesenangan. Hal ini disebabkan karena masa remaja pengaruh dari teman sebayanya sangat tinggi, karena intensitas bergaul dengan teman lebih banyak dibandingkan dengan keluarga. Senada dalam penelitian Semuel (2007) yang menunjukkan bahwa uang saku tidak memberikan pengaruh terhadap pengelolaan keuangan pribadi seseorang dalam mengatur pengeluarannya atau keputusannya dalam melakukan pembelanjaan. Dengan demikian hasil penelitian ini dapat disimpulkan bahwa tingginya pendapatan siswa tidak bisa menjamin tingginya perilaku ekonomi siswa SMA di Kecamatan pasir Belengkong dan sebaliknya.

Perilaku ekonomi siswa SMA di kecamatan Pasir Belengkong dapat dinilai dari kemampuan siswa dalam mempertimbangkan fungsi nilai dalam mengambil keputusan, memperhitungkan psikologis (mental), menentukan

probabilitas atas apa yang dilakukan, dan mempertimbangkan efek ketidakpastian. Hasil temuan ditunjukkan dari jawaban quesioner yang dilakukan oleh siswa SMA di Kecamatan Pasir Belengkong dapat diketahui bahwa siswa mampu menggunakan pertimbangan nilai (value) sebagai bahan pertimbangan pengambilan keputusan atas apa yang dilakukannya. Pertimbangan keuntungan yang pasti dan dengan pengorbanan tertentu untuk hasil yang maksimal siswa telah mampu melakukannya. Hal ini nampak dari quesioner yang disebar menunjukkan siswa banyak memilih sangat setuju dan setuju. Hal ini mengandung arti bahwa siswa telah melakukan perilaku ekonomi dari indikator pertimbangan value atau nilai. Indikator berikutnya adalah mempertimbangkan psikologis (mental), dimana dalam pernyataan ini menggunakan pernyataan perilaku siswa dalam berbelanja menggunakan pertimbangan kebutuhan, dan mempertimbangkan kwalitas dari barang yang dibeli dengan tetap berprinsip ekonomi dengan pengorbanan tertentu untuk hasil yang maksimal dan dengan pengorbanan maksimal untuk hasil tertentu. Berdasarkan hasil penelitian yang dilakukan pada siswwa SMA di kecamatan Pasir Belengkong diketahui bahwa siswa telah memiliki control diri yang baik sehingga dapat menghalau pengaruh dari lingkungan yang mendorong pada perilaku konsumtif. Selain itu pengalaman yang diperoleh sebelumnya telah membentuk sikap kedisiplinan terhadap perilaku ekonominya. Hal ini nampak dari sikap responden yang memilih sangat setuju dan setuju dalam membeli barang sesuai dengan kebutuhannya tanpa memperhatikan keinginannya. Selain itu dengan pendapatan yang sesuai dengan kebutuhan siswa yang 
bersumber dari orang tua, orang lain, bantuan dan hasil kerja sampingan dan digunakan dalam membelanjakan kebutuhan, kesenangan, tabungan dan beramal serta waktu pemberian yang sesuai dengan usianya juga mendukung perilaku ekonomi rasional dari siswa SMA di Kecamatan Pasir Belengkong. Temuan dalam indikator menentukan probabilitas atas apa yang dilakukan menunjukkan bahwa siswa SMA di kecamatan Pasir belengkong mampu menggunakan pertimbangan-pertimbangan peluang atas kepercayaan yang diyakini dengan tetap mempertimbangkan segala sesuatu yang sering terjadi dilingkungannya. Pengaruh lingkungan dan teman sebaya akan sangat kuat mempengaruhi perilaku siswa, namun akibat didukungnya kontrol diri yang kuat pada diri siswa serta adanya pengalaman-pengalaman yang diberikan oleh agen sosialisasi serta pendapatan yang disesuaikan dengan kebutuhan siswa, sehingga secara tidak langsung membentuk perilaku siswa yang rasional dalam memenuhi kebutuhannya. Kontrol diri sebagai bagian yang menentukan perilaku ekonomi siswa nampak pada sikap siswa yang mampu memilah halhal yang bersifat rasional. Besarnya pendapatan siswa secara parsial tidak berlaku signifikan terhadap perilaku ekonomi, hal ini nampak pada besar kecilnya pendapatan tidak mempengaruhi perilaku ekonomi siswa. Hal ini sesuai dengan teori pendapat yang mengatakan bahwa pendapatan sama dengan konsumsi ditambah tabungan. Jadi apabila kenaikan pendapatan tidak selalu membawa kenaikan tabungan begitu pula dengan konsumsi. Kemungkinan yang muncul dengan kenaikan pendapatan akan menaikkan konsumsi saja tabungan tetap atau konsumsi tetap tabungan naik atau keduaduanya mengalami kenaikan.

Pada indikator mempertimbangkan efek kepastian menunjukkan hasil rata-rata sangat tinggi. Hal ini dinilai dari indikator saya lebih memilih barang yang diperlukan, saya memilih belajar karena ada ujian walaupun dikampung ada pasar malam dan saya akan menyisahkan saldo saya pada saat memperoleh beasiswa/bantuan. Dari hasil angket yang diisi oleh siswa menunjukkan siswa memilih sangat setuju untuk berbelanja barang yang diperlukan, siswa memilih belajar dalam menghadapi ujian dibandingkan dengan pergi kepasar sebagai kesenangan, dan siswa lebih memilih menyisahkan saldo tabungannya pada saat mempeoleh pendapatan dibanding menghabiskannya. Hal ini menunjukkan siswa mampu berperilaku rasional dalam upaya menghadapi ketidak pastian masa depan. Peningkatan perilaku ekonomi pada siswa SMA tidak terlepas dari pengalaman-pengalaman yang dimiliki yang bersumber dari agen sosialisasi keluarga, sekolah dan lingkungan. Kontrol diri sebagai suatu sikap disiplin yang telah terbentuk dari pembiasaan-pembiasaan yang dilakukan dalam kehidupan sehari-hari. Selain itu pendapatan siswa juga memberi peran dalam rangka siswa untuk melakukan pengelolaan keuangannya. Dengan pengalaman yang diberikan oleh orang sekitar dalam mengelola keuangan akan mengajarkan dan membentuk perilaku rasional dalam kegiatan memenuhi kebutuhannya. Berdasarkan dari uraian dan kajian empiris di atas menunjukkan bahwa secara simultan antara pengalaman ekonomi, kontrol diri dan pendapatan siswa mampu mempengaruhi perilaku ekonomi siswa SMA di Kecamatan Pasir Belengkong walaupun tidak sebesar $100 \%$ pengaruhnya. karena terdapat faktor-faktor lain yang mempengaruhi dan tidak dimasukkan. 


\section{SIMPULAN}

Dari hasil penelitian dapat disimpulkan bahwa terdapat pengaruh signifikan dan positif tingkat pengalaman ekonomi terhadap perilaku ekonomi siswa SMA di Kecamatan Pasir Belengkong. Berarti tingkat intensitas pengalaman ekonomi diikuti dengan perilaku ekonomi rasional. Hal ini ditunjukkan dengan peningkatan pengalaman ekonomi yang diikuti oleh peningkatan perilaku ekonomi secara signifikan. Selanjutnya, terdapat pengaruh signifikan dan positif tingkat kontrol diri terhadap perilaku ekonomi siswa SMA di Kecamatan Pasir Belengkong. Artinya kenaikan kontrol diri diikuti oleh kenaikan perilaku ekonomi, di mana pengaruh yang ditimbulkan adalah pengaruh positif atau searah. Ketiga, tidak terdapat pengaruh signifikan antara besarnya pendapatan siswa terhadap perilaku ekonomi, artinya besarnya pendapatan siswa tidak diikuti kenaikan perilaku ekonomi. Adapun hubungan antara pendapatan siswa dengan perilaku ekonomi menunjukkan angka yang positif. Terdapat pengaruh signifikan tingkat pengalaman ekonomi dan kontrol diri serta pendapatan siswa terhadap perilaku ekonomi. Hal ini ditunjukkan bahwa ketiga variabel independen memiliki peran dalam mempengaruhi perilaku ekonomi.

\section{DAFTAR RUJUKAN}

Ajzen, I. 2005. Attitudes, Personality and Behavior. New York. USA: Open University Press.

Alwisol. 2009. Psikologi kepribadian. Malang: UMM Press.

Anderson. 1999. Perspective on learning and memory. In J.R. Anderson ed : Learning And Memory : An Integrated Approach. 2nd Edition. USA : John Wiley, Inc. p. 1, 30-31, 95-96

Arif. 2009. Teori perilaku ekonomi: Bebas nilai atau tidak bebas nilai. Social and Cultural.

Beutler dan Dickson L. 2008. Consumer economic socialization in J.J Xiao(Ed). Handbook of consumer finance research (pp.83-103). New York:Springer

Boediono. 2001. Ekonomi Makro Edisi 4. Yogyakarta: BPFE

Brooks, David. 2011. The experience economy. The New York Times. A29. Diunduh dari http://www.thenewyorktimes.org.

Dayakisni, Tri dan Hudaniah. 2003. Psikologi Sosial. UMM Press. Malang

Dodo, RW. 2008. Manajemen uang saku. Jakarta: Nobel Edumedia 
Firmansyah, Danny. 2014. The influence of family backgrounds toward student saving behavior: Asurvey of college students in Jabodetabek. International journal of Scientific and Research Publication. Volume 4. ISSN 2250-3153.

Goodwin, Neva R, Jonathan M Harris, Julie A Nelson, Brian Roach, \& Mariano Torras. (2015). Microeconomics in context. Taylor and Francis

Gudono, dan Bambang Hartadi. 1998. Apakah teori prospek tepat untuk kasus di Indonesia?: Sebuah replikasi penelitian Twesky dan Kahneman. Jurnal Riset Akuntansi Indonesia. Vol 1 No 1 Hal. 29-42

Haryanto. 2006. Teori prospek dan pembuatan keputusan:Studi empiris untuk kasus Indonesia. Jurnal Maksi. Vol.6 No.1 Januari 2006, 42-59.

Hurlock, E.B. 2002. Psikologi Perkembangan. 5th edition. Erlanga: Jakarta.

Imam, Hoyri. 2013. Kontrol diri dan perilaku konsumtif pada SMA (ditinjau dari lokasi sekolah. Jurnal Online Psikologi. Vol. 02 no.1 th. 2014.

Kahneman, Daniel. 2003. Maps of bounded rastionality: Psychology for behavioral economics. The American Economic Review. 93(5). Pp.14491475

Karim, Adiwarman Azhar 2010. Ekonomi makro Islam, Jakarta: Raja Grafindo Persada, edisi kedua.

Koentjaraningrat. 2008. Pengantar sosiologi. Jakarta: Universitas Indonesia.

Luckmann, Thomas. 2012. Tafsir sosial atas kenyataan, risalah tentang sosiologi pengetahuan. Jakarta: LP3S

Mahdzan, N.S dan Tabiani S. 2013. The impact of financial literacy on individual saving: an exploratory study in the Malaysian context. Transformation in Business and Economic. Vol 12.(1). Pp.41-55

Maksum, Ali. 2016. Sosiologi pendidikan. Malang: Madani

Mankiw, N Gregory. 2006. Pengantar ekonomi edisi kedua. Jakarta: Erlangga.

Manurung, Mandala dan Prathama Rahardja. 2004. Pengantar Ilmu Ekonomi (Mikroekonomi dan Makroekonomi). Edisi Revisi. Jakarta : Fakultas Ekonomi Universitas Indonesia.

McEachen, WA. 2001. Ekonomi Mikro. Jakarta: Salemba Empat.

Miller. J dan Yung .S. 1990. The role of allowances in adolescent socialization . Youth and society. 22(2). 137-159. 
Mischel, W., Shoda, Y. \& Rodriguez. 1992. Delay of gratification in children in G. Lowenstien \& Elster (Eds). Choise over time (pp. 147 -164).

Moefad, A.M. 2007. Perilaku individu dalam masyarakat kajian komunikasi social. Jombang: Eldeha Press Fakultas Dakwah.

Nababan, D. dan Sadalia, I. 2013. "Analisis Personal Literacy Dan Financial Behavior Mahasiswa Strata I Fakultas Ekonomi Universitas Sumatera Utara”. (Online),(http://repository.usu.ac.id./handle/123456789/34557, diakses 3 Februari 2015).

Nasution. 2009. Sosiologi pendidikan. Jakarta: Bumi Aksara.

Newman, jerry. 2008. Sosiologi pendidikan. Jakarta: Bumi Aksara

Nofzinger, J.R .2005. Social mood and financial economics, Journal of behavioral finance, 6 .

Notoatmodjo, Soekidjo. 2003. Pendidikan dan perilaku. Jakarta: Rineka Cipta.

Novita, Windya. 2013. Serba serbi anak. Jakarta: PT Alex Media Komputindo Gramedia.

Nurasiyah. A. 2010. Analisis Pengaruh LIngkungan social ekonomi terhadap perilaku konsumtif siswa (studi kasus pada SMA se kota Bandung). Jurnal Sains dan Terapan 5.1.

Otto. E. Philipp, Greg B David \& Nick Chater. 2004. Note on ways of saving: mental mechanisms as tools for self-control?" global business and economics review, vol 9.

Pine, J and Gilmore, J. 1999. The experience economy. Boston: Harvard Business School.

Rahardja, Prathama dan Mandala Manurung. 2004. Pengantar ilmu ekonomi (mikroekonomi dan makroekonomi) edisi revisi. Jakarta: Fakultas Ekonomi Universitas Indonesia.

Santrock, John . 2007. Perkembangan anak. Erlangga: Jakarta

Schuchardt, J, Hanna , S. D, Hira, T.K, Palmer, L \& Xiao, JJ. 2009. Financial literacy and education research priorities. Journal of Financial counceling and planning, 20(1), 84-95.

Scoot, R. H. III. 2010. Credit card ownership among American high school senior: 1997-2008. Journal of family and economic issues. 31(2), 151160. 
Semuel, Hatane. 2007. Pengaruh stimulus media iklan, uang saku, usia dan gender terhadap kecenderungan perilaku pembelian impulsive (studi kasus produk pariwisata). Jurnal Manajemen Pemasaran. 2 (1). Hal 31-2

Senduk, Safir. 2012, April Uang saku perlu ndak sih. Tabloid Nova. No. 938/XVIII. http://www. Tabloidnova.id.

Setyanti, Christina Andhika. 2014, Juni. Berapah sih uang yang pas untuk anak?. Tabloid Nova. Diunduh dari http://www.Tabloidnova.com.

Shadly, Hasan. 1993. Sosiologi dan masyarakat Indonesia. Jakarta: PT Rineka Cipta.

Shim S, Xiao JJ, Barber BL, Lyons A 2009. Path ways t life success: Aconceptual model of financial well being for young adults . J. Appl. Dev. Psychol. 30(6): 708-723.

Skinner. 2004. Ilmu pengetahuan dan perilaku manusia. Jakarta: Pustaka Pelajar.

Skousen, Mark. 2001. Sang maestro: teori-teori ekonomi modern. Jakarta: Predana.

Sunarto, Kamanta. 2004. Pengantar sosiologi. Jakarta: Lembaga Penerbit Fakultas Ekonomi UI.

Suryani, S. 2005. Hubungan antara status social ekonomi orang tua dalam jumlah uang saku terhadap sikap berekonomi siswa di MAN 3 Malang yang dibedakan menurut prestasi belajar. Jurnal Pendidikan Ekonomi. 9 (2). $78-88$

Syah, Muhibbin. 2003. Psikologi Belajar. Jakarta: PT. Raja Grafindo Persada.

Tanhney. JP. Baumester. RF, Boone. 2004. High self control predicts good adjustment, less pathology. Better Grade, and Interpersonal Success". Journal of Personality, 72 (2). 271-322

Wahyono, H. 2001. Pengaruh perilaku ekonomi kepada keluarga terhadap intensitas pendidikan ekonomi di lingkungan keluarga. (Disertasi yang tidak dipublikasikan). Malang: PPS UM. Nted at the IAREP conference, Micro of economic psychology. Wroclaw. Polandiar4

Webley, paul dan Ellen K. Nyhus. 2013. Economic socialization, saving and assets in European young adults. Economics of Education Review. 33 2013). 19-30. Doi: 10.1016/j.econedurev.2012.09.001. 
Webley, paul, Nythus \& Otto A.M.C, 2012. The impact of economic socialization on adult saving and spnading: A retrospective approach paper prese

Wilkinson, Nick. 2008. An Introduction to behavioral economics. New York: Palgrave Macmilan.

William, james. 2007. The principles of psychology. Vol I. New York: Inc

Yunus, Mohammmad. 2014, Oktober). Behavioral economics. Departemen hubungan internasional. Universitas Airlangga. $\mathrm{http} / /$ : unair.ac.id/artikel.1206625. 
